\title{
Pemberdayaan Komunitas Adat Terpencil (KAT) Oleh Pemerintah Daerah Kabupaten Bengkalis
}

\author{
Andriyus Andriyus ${ }^{1}$, Ranggi Ade Febrian ${ }^{2}$, Handrisal Handrisal ${ }^{3}$, Dita Fisdian Adni ${ }^{4}$ \\ 1,2,4Program Studi Ilmu Pemerintahan, Fakultas Ilmu Sosial dan Ilmu Politik, \\ Universitas Islam Riau, Kota Pekanbaru, Provinsi Riau \\ 3Program Studi Ilmu Pemerintahan, Fakultas Ilmu Sosial dan Ilmu Politik, \\ Universitas Maritim Raja Ali Haji, Kota Tanjungpinang, Provinsi Kepulauan Riau
}

Corresponding Author: andriyus@soc.uir.ac.id

Keyword:

Empowerment;

Remote Indigenous;

Communities;

Local Government;

\begin{abstract}
In general, the problem associated with Remote Indigenous Communities is accessibility to public facilities that enable them to transform their lives into a better direction. Lack of accessibility to the outside world which causes Remote Indigenous people to fall into various aspects of life such as poverty, low health levels, education levels and others. The purpose of this study was to analyze the Remote Indigenous Community Empowerment by the Bengkalis Regency Government. The results of this study are useful as information and input from the Bengkalis Regency Government in making policies related to the empowerment of Remote Traditional Communities in the Bengkalis Regency Regional Government. The results of this study indicate that the empowerment of Remote Indigenous Communities carried out by the Bengkalis Regency Government. not running properly because seen from human empowerment, social environment and social protection and advocacy is still limited to providing assistance for facilities and infrastructure, there are no concrete steps to improve the quality of the isolated indigenous community. The existence of barriers to empowerment is the limited budget and not yet open to the community of Remote Indigenous Communities to receive new things.
\end{abstract}

\section{PENDAHULUAN}

Hakekat pembangunan nasional adalah pembangunan manusia seutuhnya dengan berpedoman pada Undang-Undang Dasar 1945 dan Pancasila, Pembangunan nasional dilaksanakan secara merata diseluruh tanah air diperuntukkan bagi seluruh rakyat Indonesia sebagai upaya perbaikan tingkat hidup yang berkeadilan sosial sesuai dengan tujuan dan cita-cita dari kemerdekaan bangsa Indonesia. Pelaksanaan pembangunan nasional merupakan usaha kegiatan yang dilakukan secara sadar, terencana dan bertanggung jawab dalam mencapai tujuan kearah perubahan-perubahan yang lebih baik yakni kesejahteraan dan kemakmuran yang merata bagi seluruh rakyat Indonesia. Pembangunan harus dilaksanakan berdasarkan tujuan yang telah ditetapkan sehingga dapat menciptakan suatu perubahan-perubahan, namun perubahan tersebut harus secara terencana dan berkesinambungan agar dapat meningkatkan kualitas hidup manusia.

Menurut Peraturan Menteri Sosial Republik Indonesia Nomor 09 Tahun 2012 Tentang Pemberdayaan Komunitas Adat Terpencil yang dimaksud dengan Komunitas Adat Terpencil (KAT) adalah kelompok sosial budaya yang bersifat lokal dan terpencar serta kurang atau belum terlibat dalam jaringan dan pelayanan, baik sosial, ekonomi maupun politik. Adapun ciri-ciri Komunitas Adat Terpencil (KAT) sebagaimana 
dijelaskan dalam pasal 4 adalah terdiri atas sekumpulan orang dalam jumlah tertentu yang terikat oleh kesatuan geografis, ekonomi, sosial budaya, miskin, terpencil, dan/atau rentan sosial ekonomi. Yang memiliki kriteria keterbatasan akses pelayanan sosial dasar, tertutup, homogen, kehidupannya tergantung pada sumber daya alam, marjinal di pedesaan, tinggal di wilayah perbatasan antar negara, wilayah pesisir, pulau-pulau terluar, dan/atau terpencil.

Komunitas Adat Terpencil (KAT) sebagai bagian dari penduduk Indonesia merupakan lapisan paling bawah dalam struktur dan perkembangan masyarakat. Komunitas Adat Terpencil menghadapi berbagai ketertinggalan dalam pencapaian pemenuhan kebutuhan dasar hidup sebagai manusia, hal ini terjadi sebagai konsekuensi dari keberadaan mereka yang secara geografis sangat sulit dijangkau dan secara sosial termasuk dalam budaya terasing, sehingga interaksi sosial dengan kelompok masyarakat luar yang lebih maju kurang terjalin baik. Pengelolaan pendidikan Komunitas Adat Terpencil (KAT) tidak dapat disamakan dengan pendidikan pada sekolah umumnya karena permasalahan sosial yang dihadapi sifatnya sangat kompleks meliputi segi kehidupan. Pemerintah selaku penyelenggara harus menjadi aktor utama sebagai wujud pelaksana amanah Undang-Undang Dasar 1945 untuk mensejahterakan seluruh rakyat Indonesia. Kabupaten Bengkalis merupakan salah satu kabupaten yang terdapat kelompok masyarakat Komunitas Adat Terpencil (KAT), yang tersebar dibeberapa Kecamatan, untuk lebih jelasnya penulis uraikan ada tabel berikut :

\begin{tabular}{|l|c|c|c|}
\hline \multicolumn{1}{|c|}{ Kecamatan } & $\begin{array}{c}\text { Komunitas Adat } \\
\text { Terpencil (KAT) }\end{array}$ & KK & Jiwa \\
\hline Bantan & Suku Akit & 1.125 & 6.350 \\
\hline Mandau & Suku Sakai & 1.982 & 10.892 \\
\hline Pinggir & Suku Sakai & 1.089 & 5.995 \\
\hline & & $\mathbf{9 0 8}$ & $\mathbf{9 0}$ \\
\hline
\end{tabular}

Tabel 1. Jumlah Komunitas Adat Terpencil (KAT) di Kabupaten Bengkalis Sumber : Dinas Sosial Kabupaten Bengkalis 2019

Permasalahan yang dihadapi oleh masyarakat Komunitas Adat Terpencil (KAT) yang ada di Kabupaten Bengkalis tidak jauh berbeda dari permasalahan Komunitas Adat Terpencil (KAT) diwilayah lain di Indonesia yaitu terbatasnya akses mereka terhadap pelayanan publik, mereka hidup dibawah garis kemiskinan dan mayoritas memiliki tingkat pendidikan yang relatif rendah. Pemerintah Daerah Kabupaten Bengkalis sudah membuat suatu kebijakan atau kegiatan yang mengarah pada penangan masalah Komunitas Adat Terpencil (KAT) tersebut. Adapun program tersebut yaitu program pemberdayaan Komunitas Adat Terpencil (KAT). Program ini bertujuan untuk memberdayakan dan lebih meningkatkan kesejateraan warga Komunitas Adat Terpencil (KAT). Dimana pemberdayaan adalah upaya pemberian daya atau peningkatan keberdayaan serta untuk memampukan dan memandirikan warga agar mampu berpartisipasi aktif dalam segala aspek pembangunan.

Berbagai macam kegiatan pemberdayaan sudah diberikan oleh Pemerintah Daerah Kabupaten Bengkalis baik berupa pemberian bantuan rumah layak huni, bantuan seragam sekolah, makanan penambah gizi serta bantuan tempat penampungan air bersih maupun dalam bentuk pemberian pendidikan dan pelatihan bagi masyarakat Komunitas Adat Terpencil (KAT), kegiatan pemberdayaan ini diselenggarakan setiap tahun oleh Pemerintah Daerah Kabupaten Bengkalis dan dianggarkan dalam Anggaran Pendapatan dan Belanja Daerah. Akan tetapi tidak berbanding lurus dengan kondisi masyarakat Komunitas Adat Terpencil (KAT) tersebut, yang sampai saat ini belum ada peningkatan 
kesejahteraan mereka secara signifikan sebagaimana sasaran yang ingin dicapai dalam program pemberdayaan tersebut.

Penelitian terdahulu adalah upaya peneliti mencari perbandingan dan selanjutnya untuk menemukan inspirasi baru untuk penelitian selanjutnya disamping itu kajian terdahulu membantu penelitian dalam memposisikan penelitian serta menunjukkan orisinalitas dari penelitian. Penelitian terdahulu ini menjadi salah satu acuan penulis dalam melakukan penelitian sehingga penulis dapat memperkaya teori yang digunakan dalam mengkaji penelitian yang dilakukan. Dari penelitian terdahulu, penulis tidak menemukan penelitian dengan judul yang sama seperti judul penelitian penulis. Namun penulis mengangkat beberapa penelitian sebagai referensi dalam memperkaya bahan kajian pada penelitian penulis yaitu sebagai berikut :

Penelitian yang dilakukan oleh Yulinawati tentang Program Pemberdayaaan Komunitas Adat Terpencil (KAT) di Desa Sungai Tohor Barat Kecamatan Tebing Tinggi Timur Kabupaten Kepulauan Meranti, dalam penelitiannya peneliti menggunakan metode penelitian kualitatif. Hasil penelitian ini menunjukkan bahwa Pemberdayaan warga Komunitas Adat Terpencil (KAT) di Desa Sungai Tohor Barat belum mencapai empat indikator pemberdayaan yaitu kemandirian, partisipatif, jaringan kerja dan keadilan. Karena masih kurangnya keterlibatan atau partisipasi dari dinas-dinas atau instansi terkait dalam pemberdayaan Komunitas Adat Terpencil (KAT). Kurang sinkronnya antara data Komunitas Adat Terpencil (KAT) dengan data jumlah bantuan yang diberikan. Kurangnya koordinasi keberlanjutan antara pemerintah daerah dengan pemerintah desa mengenai kondisi warga Komunitas Adat Terpencil (KAT). Sehingga akan berakibat nantinya warga Komunitas Adat Terpencil (KAT) akan kembali pada kondisi kehidupan mereka semula.

Penelitian Riau Sujarwanni, Fitri Dewi Wulandari, Alfi Husni, Faizal Rianto dan Sarinah tentang Pemberdayaan Masyarakat Komunitas Adat Terpencil (KAT) oleh Pemerintah Kabupaten Lingga Kepulauan Riau. Dalam penelitiannya peneliti menggunakan jenis penelitian deskriptif. Hasil penelitian ini menunjukkan bahwa pemberdayaan dilakukan dengan tiga indikator pemberdayaan yaitu reorientasi, gerakan sosial dan institusi lokal. Reorientasi diketahui bahwa social lisasi sudah dilakukan. Sosialisasi yang dilakukan dengan meninjau langsung para suku laut untuk mengetahuiapa yang mereka butuhkan, seperti dilakukan sosialisasi mengenai bantuan rumah tidak layak huni, dan bantuan keluarga harapan. Namun komunitas adat terpencil yang ada di Desa Tajur biru belum bisa menerima sepenuhnya perubahan, karena mereka tetap memilih untuk tinggal di laut. Dalam sebulan minimal sekali dilakukan sosialisasi lewat kegiatan yang sedang dilakukan masyarakat di Desa Tajur Biru. Sosialisasi sangat diperlukan untuk memperkenalkan adanya program pember dayaan komunitas adat terpencil.

Gerakan sosial diketahui bahwa Pemerintah telah menyediakan dana bantuan kepada masyarakat suku laut yang sangat membantu masyarakat untuk membuat usaha budidaya perikanan serta industri lainnya dan juga pihak dinas kepada masyarakat yang ingin membuat modal usaha dengan membutuhkan pinjaman kepada pihak koperasi yang mana masyarakat dapat melangsungkan kegiatan industri di bidang perikanan dan kelautan yang dapat membangun ekonomi masyarakat, dan mendorong partisipasi masyarakat dalam melaksanakan program pemberdayaan komunitas terpencil ini, bentuk partisipasi bisa dengan cara bermacam-macam salah satunya mau menerima suku laut di wilayahnya, memberikan pengetahuan terhadap apa agama, dan normanorma yang berlaku. Institusi lokal diketahui bahwa peran pemerintah sejauh ini masih belum optimal karena pemerintah memfokuskan pada sosialisasi dan pengetahuan masyarakat komunitas adat terpencil terhadap program pemberdayaan, namun tidak 
diiringi dengan pembangunan sarana prasana serta fasilitas yang dibutuhkan masyarakat seperti pendidikan dan kesehatan. Kendala yang terjadi adalah selama ini pemerintah sebagai instansi lokal hanya memberikan pembinaan, pelatihan dan pemahaman terhadap pemberdayaan Komunitas Adat Terpencil, namun sarana prasarana belum dapat dilengkapi dengan baik seperti sarana prasarana pendidikan, tempat ibadah dan layanan kesehatan.

Penelitian Della Maiyoza Putri tentang Peranan Dinas Sosial Kabupaten Bengkalis Dalam Memberdayakan Komunitas Adat Terpencil di Kabupaten Bengkalis. Dalam penelitian ini peniliti menggunakan metode kuantitatif dengan jenis survey deskriptif. Hasil penelitian ini menunjukkan bahwa dinas Sosial Kabupaten Bengkalis cukup berperan dalam memberdayakan masyarakat Komunitas Adat Terpencil dalam mesejahtrakan kehidupan masyarakat Komunitas Adat Terpencil dan juga membantu kebutuhan Masyarakat Komunitas Adat Terpencil dari segi perekonomian kesehatan dan pendidikan, hal ini dilihat dari pemberdayaan sumber daya manusia, pemberdayaan lingkungan sosial serta pemberdayaan sosial dan advokasi.

Secara konseptual, pemberdayaan atau pemerkuasaan (empowerment) berasal dari kata power (kekuasaan atau keberdayaan). Karena ide utama pemberdayaan bersentuhan dengan kemampuan untuk membuat orang lain melakukan apa yang kita inginkan, terlepas dari keinginan dan minat mereka (Edi Suharto, 2005:57). Prijono dan Pranarka (1996: 77) menyatakan bahwa pemberdayaan mengandung dua arti. Pengertian yang pertama adalah to give power or authority, pengertian kedua to give ability to or enable. Pemaknaan pengertian pertama meliputi memberikan kekuasaan, mengalihkan kekuatan atau mendelegasikan otoritas kepada pihak yang kurang/ belum berdaya. Di sisi lain pemaknaan pengertian kedua adalah memberikan kemampuan atau keberdayaan serta memberikan peluang kepada pihak lain untuk melakukan sesuatu.

Berkenaan dengan pemaknaan konsep pemberdayaan masyarakat, Winarni mengungkapkan bahwa inti dari pemberdayaan adalah meliputi tiga hal yaitu pengembangan, (enabling), memperkuat potensi atau daya (empowering), terciptanya kemandirian (Tri Winarni, 1998: 75). Pemberdayaan memiliki makna membangkitkan sumber daya, kesempatan, pengetahuan dan keterampilan masyarakat untuk meningkatkan kapasitas dalam menentukan masa depan mereka (Suparjan dan Hempri, 2003: 43). Konsep utama yang terkandung dalam pemberdayaan adalah bagaimana memberikan kesempatan yang luas bagi masyarakat untuk menentukan sendiri arah kehidupan dalam komunitasnya.

Pemberdayaan menurut (Suhendra, 2006:74-75) adalah "suatu kegiatan yang berkesinambungan dinamis secara sinergis mendorong keterlibatan semua potensi yang ada secara evolutif dengan keterlibatan semua potensi". Selanjutnya pemberdayaan menurut Jim Ife (dari buku Suhendra, 2006:77) adalah "meningkatkan kekuasaan atas mereka yangkurang beruntung (empowerment aims to increase the power of disadvantage)". Menurut (Moh. Ali Aziz dkk, 2005: 169) pemberdayaan adalah sebuah konsep yang fokusnya adalah kekuasaan. Pemberdayaan secara substansial merupakan proses memutus (breakdown) dari hubungan antara subjek dan objek. Proses ini mementingkan pengakuan subjek akan kemampuan atau daya yang dimiliki objek. Secara garis besar proses ini melihat pentingnya mengalirkan daya darisubjek ke objek. Hasil akhir dari pemberdayaan adalah beralihnya fungsi individu yang semula objek menjadi subjek (yang baru), sehingga relasi sosial yang nantinya hanya akan dicirikan dengan relasi sosial antar subyek dengan subyek lain.

Menurut Sumaryadi (2005:11) pemberdayaan masyarakat adalah upaya mempersiapkan masyarakat seiring dengan langkah memperkuat kelembagaan masyarakat agar mereka mampu mewujudkan kemajuan, kemandirian, dan 
kesejahteraan dalam suasana keadilan sosial yang berkelanjutan. Selain itu pemberdayaan masyarakat menurut Sumaryadi sebagai berikut:

a. Membantu pengembangan manusiawi yang autentik dan integral dari masyarakat lemah, rentan, miskin perkantoran, masyarakat adat yang terbelakang, kaum muda pencari kerja, kaum cacat dan kelompok wanita yang didiskriminasikan/dikesampingkan.

b. Memberdayakan kelompok-kelompok masyarakat tersebut secara sosial ekonomis sehingga mereka dapat lebih mandiri dan dapat memenuhi kebutuhan dasar hidup mereka, namun sanggup berperan serta dalampengembangan masyarakat. Dari pendapat tersebut maka pemberdayaan masyarakat adalah upaya untuk meningkatkan harkat dan martabat lapisan masyarakat yang dalam kondisi sekarang tidak mampu melepaskan diri dari perangkap kemiskinan dan keterbelakangan.

Menurut Widjaja (2003:169) pemberdayaan masyarakat adalah upaya meningkatkan kemampuan dan potensi yang dimiliki masyarakat sehingga masyarakat dapat mewujudkan jati diri harkatdan martabatnya secara maksimal untuk bertahan dan mengembangkan diri secara mandiri baik di bidang ekonomi, sosial, agama dan budaya. Abu Huraerah (2008:87) mengatakan bahwa pemberdayaan masyarakat adalah sebuah proses dalam bingkai usaha memperkuat apa yang lazim disebut community self-reliance atau kemandirian. Dalam proses ini masyarakat didampingi untuk membuat analisis masalah yang dihadapi, dibantu untuk menemukan alternatif solusi masalah tersebut, serta diperlihatkan strategi memanfaatkan berbagai kemampuan yang dimiliki.

Menurut Sumodiningrat (dalam Ambar Teguh, 2004: 82) pemberdayaan tidak bersifat selamanya, melainkan sampai target masyarakat mampu untuk mandiri, meski dari jauh di jaga agar tidak jatuh lagi. Dilihat dari pendapat tersebut berarti pemberdayaan melalui suatu masa proses belajar hingga mencapai status mandiri, meskipun demikian dalam rangka mencapai kemandirian tersebut tetap dilakukan pemeliharaan semangat, kondisi dan kemampuan secara terus menerus supaya tidak mengalami kemunduran lagi. Sebagaimana disampaikan dimuka bahwa proses belajar dalam rangka pemberdayaan masyarakat akan berlangsung secara bertahap. Tahaptahap yang harus dilalui tersebut adalah meliputi tahap penyadaran dan tahap pembentukan perilaku menuju perilaku sadar dan peduli sehingga merasa membutuhkan kapasitas diri dan Tahap transformasi kemampuan berupa wawasan pengetahuan, kecakapan keterampilan agar terbuka wawasan dan memberikan keterampilan dasar sehingga dapat mengambil peran di dalam pembangunan. 3. Tahap peningkatan kemampuan intelektual, kecakapan keterampilan sehingga terbentuklah inisiatif dan kemampuan inovatif untuk mengantarkan pada kemandirian (Ambar Teguh, 2004: 83).

Komunitas Adat Terpencil (KAT) merupakan sekumpulan orang dalam jumlah tertentu yang terikat oleh kesatuan geografis, ekonomi, dan/atau sosial budaya, dan miskin, terpencil, dan/atau rentan sosial ekonomi. Adapaun ciri-ciri dari Komunitas Adat Terpencil (KAT) ialah sebagai berikut : Keterbatasan akses pelayanan sosial dasar, tertutup, homogen, dan penghidupannya tergantung kepada sumber daya alam, marjinal di pedesaan dan perkotaan, tinggal di wilayah perbatasan antar negara, daerah pesisir, pulau-pulau terluar, dan terpencil. Komunitas Adat Terpencil (KAT) dalam pemenuhan kebutuhan sehari-harinya sangat serba keterbatasan, seperti alat-alat yang mereka gunakan untuk mencari ikan atau berburu masih menggunakan alat-alat tradisional. Warga Komunitas Adat Terpencil (KAT) berinteraksi dengan masyarakat lainnya masih sangat terbatas, mereka bergantung pada sumber daya alam yang ada di sekitar mereka dalam memenuhi kehidupan. Selain itu, dalam satu rumah dihuni dua hingga tiga kepala keluarga, dalam pengobatan mereka masih menggunakan ramuantradisional. Mereka 
hanya manggunakan lampu yang terbuat dari minyak tanah untuk menerangi rumah mereka dari kegelapan, air yang mereka konsumsi sehari-hari berasal dari air sumur. Mereka tidak memiliki mck yang tertutup atau khusus, warga Komunitas Adat Terpencil (KAT) masih berpegang teguh pada adat istiadat mereka dalam menjalankan kehidupan. Dengan kondisi yang keterbatasan menyebabkan mereka tidak berdaya, tertinggal dan ketidakmampuan dalam memenuhi kebutuhan dasar mereka.

Menurut Peraturan Menteri Sosial Republik Indonesia Nomor 09 Tahun 2012 Tentang Pemberdayaan Komunitas Adat Terpencil yang dimaksud dengan Komunitas Adat Terpencil yang selanjutnya disingkat dengan KAT adalah kelompok sosial budaya yang bersifat lokal dan terpencar serta kurang atau belum terlibat dalam jaringan dan pelayanan, baik sosial, ekonomi maupun politik. Pemberdayaan Komunitas Adat Terpencil adalah serangkaian kebijakan, strategi, program dan kegiatan yang diarahkan pada upaya pemberian kewenangan dan kepercayaan kepada KAT setempat untuk menemukan masalah dan kebutuhan beserta upaya pemecahannya berdasarkan kekuatan dan kemampuan sendiri, melalui upaya perlindungan, penguatan, pengembangan, konsultasi dan advokasi guna peningkatan taraf kesejahteraan sosialnya.

Dalam pasal 2 ayat (1) dijelaskan bahwa Pemberdayaan KAT dimaksudkan agar taraf kesejahteraan sosial warga KAT lebih meningkat melalui serangkaian kegiatan pemberdayaan KAT. Selanjutnya dalam ayat (2) dijelaskan Pemberdayaan KAT bertujuan untuk (a) Memenuhi kebutuhan sosial dasar warga Komunitas Adat Terpencil (KAT) meliputi pemenuhan kebutuhan sarana dan prasarana infrastruktur sederhana, pendidikan, seni dan budaya; dan/atau (b) Mewujudkan kesejahteraan sosial bagi warga Komunitas Adat Terpencil (KAT) melalui proses pembelajaran sosial dengan menghormati inisiatif dan kreativitas warga dalam memenuhi kebutuhan dan hak-hak dasarnya sehingga warga Komunitas Adat Terpencil (KAT) dapat mengaktualisasikan diri dalam lingkungannya secara wajar, baik jasmani, rohani, dan sosial untuk dapat berperan aktif dalam pembangunan.

Pemberdayaan Komunitas Adat Terpencil (KAT) tediri atas dua tahapan yaitu tahap persiapan dan tahap pelaksanaan. Tahap persiapan itu meliputi :

a. Pemetaan sosial, merupakan kegiatan pengumpulan data dan informasi awal tentang keberadaan lokasi KAT yang diidentifikasi sesuai dengan pengertian dan ciri-ciri KAT.

b. Penjajakan awal, merupakan verifikasi data KAT yang diajukan pemerintah provinsi berdasarkan prioritas yang tercantum dalam data base persebaran KAT, dengan mengunakan alat ukur berupa instrumen untuk penetapan lokasi KAT termasuk kategorisasinya berdasarkan jumlah total skoring.

c. Studi kelayakan, dilakukan pada lokasi yang telah dilaksanakan penjajakan awal dan telah ditetapkan dalam kategorisasi KAT berdasarkan alat ukur berupa instrumen yang telah dibuat skoring serta upaya identifikasi masalah dan kebutuhan warga dilokasi KAT.

d. Seminar dan lokakarya (semiloka), terdiri dari :

- Seminar dan lokakarya daerah, merupakan kegiatan presentasi hasil studi kelayakan yang dilaksanakan di provinsi atau kabupaten untuk mendapatkan kesepakatan dan rekomendasi sebagai bahan penyusunan laporan untuk seminar dan lokakarya nasional;

- Seminar dan lokakarya nasional, merupakan kegiatan untuk menindaklanjuti seminar dan lokakarya daerah, untuk mengetahui jumlah usulan kepala keluarga dari setiap provinsi, dan jumlah estimasi yang dapat dipenuhi disesuaikan dengan pagu anggaran yang tersedia pada tahun depan.

e. Penyusunan rencana dan program, dibuat berdasarkan rekomendasi hasil studi kelayakan yang telah disemilokakan di tingkat pusat dan daerah. 
f. Penyiapan kondisi masyarakat, dilaksanakan dalam bentuk bimbingan dan motivasi pada calon lokasi pemberdayaan KAT yang telah dilaksanakan kegiatan studi kelayakan dan semiloka serta mempersiapkan calon warga binaan KAT agar berpartisipasi sesuai dengan pilihan dan aspirasinya selama periode waktu pemberdayaan.

Sedangkan tahap pelaksanaan pemberdayaan Komunitas Adat Terpencil (KAT) meliputi :

a. Pemberdayaan sumber daya manusia; Merupakan usaha peningkatan kualitas KAT yang meliputi berbagai aspek kehidupan seperti komunikasi, interaksi, tumbuhnya rasa kebersamaan, rasa aman, pendidikan, kesehatan, kehidupan beragama, dan penghidupan seperti kemampuan melaksanakan usaha pertanian, perkebunan, perikanan, keterampilan dalam rangka peningkatan perekonomian warga, koperasi, kemitraan.

b. Pemberdayaan lingkungan sosial merupakan usaha peningkatan kualitas lingkungan sosial KAT terdiri atas :

- Penataan permukiman di tempat asal (insitu) merupakan pemukiman warga KAT pada orbitasinya sebagaimana batas wilayahnya ditentukan oleh titik koordinat (poligon tertutup) pada saat penjajakan awal dan studi kelayakan;

- Penataan perumahan dan permukiman ditempat baru (exsitu) merupakan pemukiman warga KAT diluar orbitasi awal sebagaimana batas wilayahnya ditentukan oleh titik koordinat baru pada saat penjajakan awal dan studi kelayakan; dan

- Segala sesuatu yang berkaitan dengan kepemilikan warga KAT ditempat asal dan/atau tempat baru harus diberikan perlindungan.

c. Perlindungan sosial dan advokasi sosial.

Dimaksudkan sebagai upaya melindungi dan membela KAT yang dilanggar haknya diberikan dalam bentuk penyadaran hak dan kewajiban, pembelaan, dan pemenuhan hak.

\section{METODE PENELITIAN}

Pendekatan yang digunakan dalam penelitian ini adalah menggunakan pendekatan kualitatif yang menghasilkan data deskriptif yang berkaitan dengan pemberdayaan Komunitas Adat Terpencil yang dilakukan oleh Pemerintah Daerah Kabupaten Bengkalis. Metode penelitian kualitatif ini sering disebut metode penelitian naturalistik karena penelitiannya dilakukan pada kondisi yang alamiah (natural setting) mengenai realitas pemberdayaan Komunitas Adat Terpencil yang dilakukan oleh Pemerintah Daerah Kabupaten Bengkalis. Metode pengumpulan data yang peneliti gunakan adalah observasi, wawancara dan dokumentasi yang akan dilakukan kepada informan dan key informan yang sudah ditentukan. Metode pengolahan data dilakukan dengan cara data penelitian yang telah dikumpulkan melalui pengamatan lansung, wawancara mendalam, dokumendokumen pendukung, kemudian diolah sesuai dengan permasalahan yang diangkat, dalam beberapa tahapan-tahapan yaitu pengumpulan data, reduksi data, penyajian data dan verifikasi data untuk selanjutnya ditarik kesimpulan.

\section{HASIL DAN PEMBAHASAN}

\section{Pemberdayaan Sumber Daya Manusia}

Pemberdayaan sumber daya manusia dalam penelitian ini adalah usaha yang dilakukan oleh Pemerintah Daerah Kabupaten Bengkalis dalam meningkatkan kualitas Komunitas Adat Terpencil yang meliputi berbagai aspek kehidupan seperti komunikasi, interaksi, tumbuhnya rasa kebersamaan, rasa aman, pendidikan, kesehatan, kehidupan 
beragama, dan penghidupan seperti kemampuan melaksanakan usaha pertanian, perkebunan, perikanan, keterampilan dalam rangka peningkatan perekonomian warga, koperasi, kemitraan. Pemberdayaan sumber daya manusia Komunitas Adat Terpencil ini meliputi peningkatan kualitas pendidikan warga Komunitas Adat Terpencil, peningkatan kualitas kesehatan warga Komunitas Adat Terpencil, peningkatan kemampuan usaha pertanian, perkebunan dan perikanan serta peningkatan keterampilan dalam meningkatkan perekonomian.

Dalam hal peningkatan kualitas pendidikan warga Komunitas Adat Terpencil, Pemerintah Daerah Kabupaten Bengkalis melalui Dinas Sosial sudah melakukan upaya peningkatan kualitas warga Komunitas Adat Terpencil melalui pemberian akses seluasluasnya bagi masyarakat Komunitas Adat Terpencil untuk menempuh pendidikan formal serta memberikan bantuan perlengkapan sekolah berupa seragam sekolah, tas dan buku serta perlengkapan sekolah lainnya. Sebagaimana hasil wawancara dengan Kepala Dinas Sosial Kabupaten Bengkalis, Dra. Hj. Martini, MH mengatakan bahwa dalam rangka peningkatan kualitas pendidikan bagi masyarakat Komunitas Adat Terpencil yang ada diwilayah Kabupaten Bengkalis kita dari Dinas Sosial sudah melakukan upaya program dan kegiatan berupa pemberian bantuan sarana dan sarana pendidikan berupa perlengkapan sekolah bagi anak-anak masyarakat Komunitas Adat Terpencil disetiap jenjang pendidikan. Hal ini juga diaminkan oleh Camat Bantan Drs. Sufandi, MP dalam wawancara penelitian mengatakan bahwa Dinas Sosial memang sudah memberikan bantuan untuk menunjang pendidikan masyarakat Komunitas Adat Terpencil yang ada diwilayah kerjanya berupa perlengkapan sekolah walaupun memang belum seluruh masyarakat Komunitas Adat Terpencil yang mendapat bantuan tersebut karna juga harus berbagi dengan masyakarat yang ada diwilayah kecamatan yang lain.

Kemudian dalam hal peningkatan kualitas kesehatan masyarakat Komunitas Adat Terpencil, dari hasil penelitian lapangan yang sudah dilakukan diketahui bahwa Pemerintah Daerah Kabupaten Bengkalis sudah melakukan upaya peningkatan kualitas kesehatan masyarakat Komunitas Adat Terpencil melalui dinas kesehatan dan dinas sosial dalam bentuk menggiatkan aktifitas posyandu yang ada dilingkungan masyarakat Komunitas Adat Terpencil, disamping itu pemerintah daerah juga memberikan bantuan asupan gizi tambahan bagi anak-anak masyarakat Komunitas Adat Terpencil berupa pemberian susu, bubur kacang hijau dan sebagainya melalui posyandu yang ada. Sebagaimana hasil wawancara penelitian dengan Cong Meng Kepala Desa Pambang Baru Kecamatan Bantan yang merupakan termasuk masyarakat Komunitas Adat Terpencil mengatakan bahwa pemerintah daerah memang sudah ada memberikan bantuan susu dan asupan gizi lainnya khusus untuk balita saja tapi hanya sebatas itu untuk yang lain lainnya selama ini belum ada.

Selanjutnya dalam hal peningkatan kemampuan usaha pertanian, perkebunan dan perikanan bagi masyarakat Komunitas Adat Terpencil menurut peneliti belum berjalan dengan baik karena Pemerintah Daerah Kabupaten Bengkalis hanya sebatas memberikan peralatan perikanan sedangkan tatacara penggunaannya tidak ada dilakukan pelatihan padahal tidak semua masyarakat Komunitas Adat Terpencil yang bisa menggunakan alat tersebut. sedangkan untuk bidang pertanian dan perkebunan tidak ada sama sekali upaya yang dilakukan oleh pemerintah daerah memang mayoritas masyarakat Komunitas Adat Terpencil mata pencahariannya nelayan akan tetapi bukan tidak ada yang memiliki usaha pertanian dan perkebunan. Hasil wawancara penelitian dengan Kepala Bidang Pemberdayaan Sosial Drs. Feni Hafzan mengatakan bahwa Dinas Sosial selama ini memang memfokus pada upaya pemberdayaan dibidang perikanan dengan pertimbangan masyarakat warga Komunitas Adat Terpencil mayoritas tinggal dipingiran laut dan sungai dengan nelayan sebagai pekerjaan sehari-hari. Upaya pemberdayaan ini 
kami lakukan secara bertahap karena mayoritas mereka mencari ikan maka kami mengutamakan dibidang perikanan sedangkan dibidang pertanian dan perkebunan untuk tahapan berikutnya.

Selanjutnya dalam hal peningkatan keterampilan dalam meningkatkan perekonomian bagi masyarakat Komunitas Adat Terpencil berdasarkan hasil temuan penelitian belum ada sama sekali upaya yang dilakukan oleh Pemerintah Daerah Kabupaten Bengkalis dalam meningkatkan keterampilan yang tujuan akhirnya akan berdampak pada peningkatan perekonomian masyarakat Komunitas Adat Terpencil tersebut.

\section{Pemberdayaan Lingkungan Sosial}

Pemberdayaan lingkungan sosial dalam penelitian ini adalah usaha yang dilakukan oleh Pemerintah daerah Kabupaten Bengkalis dalam peningkatan kualitas lingkungan sosial Komunitas Adat Terpencil yang terdiri atas penataan permukiman serta perlindungan kepemilikian terhadap segala yang mereka miliki. Dalam hal penataan pemukiman masyarakat Komunitas Adat Terpencil dari hasil penelitian penulis sudah ada kegiatan yang dilakukan oleh Pemerintah Daerah Kabupaten Bengkalis dalam menata pemukiman Komunitas Adat Terpencil yaitu dengan memberikan sarana penampungan air bersih dan pemberian rumah layak huni, khusus untuk rumah layak huni yang diberikan oleh pemerintah tidak dimanfaatkan oleh masyarakat penerima bantuan mereka lebih suka dirumah mereka sendiri dengan kondisi seadanya dan bahkan ada yang ingin menjual rumah bantuan tersebut. Hasil dari wawancara penulis dengan Camat Bantan Drs. Sufandi, MP mengatakan bahwa Pemerintah Daerah Kabupaten Bengkalis melalui Dinas Sosial sudah memberikan bantuan rumah layak huni untuk masyarakat Komunitas Adat Terpencil akan tetapi belum seluruh masyarakat Komunitas Adat Terpencil yang layak mendapat bantuan tersebut dapat menerima karena juga harus berbagi.

Hal tersebut juga di aminkan oleh Kepala Desa Jangkang Edi Sutrisno, SE, mengatakan bahwa Desa Jangkang merupakan salah satu desa yang terdapat masyarakat Komunitas Adat Terpencil yaitu suku Akit, dan pemerintah daerah sudah memberikan bantuan rumah layak huni walaupun masih belum mencukupi karena setiap desa yang memiliki masyarakat Komunitas Adat Terpencil diberi jatah unit rumah layak huni bukan berdasarkan jumlah masyarakat yang rumahnya sudah tidak layak untuk dihuni. Sedangkan dalam hal perlindungan terhadap semua kemilikan masyarkat Komunitas Adat Terpencil berdasarkan hasil penelitian sampai saat ini belum ada bentuk usaha pemerintah daerah dalam melindungi kepemilikan mereka kecuali pemberian sertifikat tanah bagi masyarakat yang sudah memenuhi persyaratan dan itupun masyarakatnya yang mengurus melalui pemerintah desa.

\section{Perlindungan Sosial dan Advokasi Sosial}

Perlindungan sosial dalam konteks penelitian ini adalah kebijakan yang dibuat oleh Pemerintah Daerah Kabupaten Bengkalis untuk mencegah dan menangani resiko serta kerentanan sosial Komunitas Adat Terpencil agar kelangsungan hidupnya dapat dipenuhi sesuai dengan kebutuhan dasar minimal. Sedangkan advokasi sosial dalam penelitian ini adalah sebagai upaya melindungi dan membela Komunitas Adat Terpencil yang dilanggar haknya diberikan dalam bentuk penyadaran hak dan kewajiban, pembelaan, dan pemenuhan hak.

Berkaitan dengan melindungi dan membela hak Komunitas Adat Terpencil pemerintah sudah melakukan upaya-upaya untuk melindungi hak-hak warga Komunitas Adat Terpencil supaya tidak dilanggar, karena hak masyarakat Komunitas Adat Terpencil 
sama dengan hak masyarakat lain pada umumnya tidak pembedaan dan pemerintah daerah menjamin akan terpenuhinya hak-hak mereka terutama hak-hak dasar, dan pemerintah daerah juga selalu aktif memberikan pemahaman kepada masyarakat Komunitas Adat Terpencil tentang hak dan kewajiban mereka sebagai anggota masyarakat baik yang dilakukan melalui sosialisasi maupun melalui seminar-seminar. Berdasarkan wawancara penelitian dengan Camat Bantan, mengatakan bahwa Selama ini kecamatan Bantan selalu memperhatikan masyarakat komunitas adat terpencil dari segi perekonomian, kesehatan dan pendidikan dan kami selalu melihat apa yang diigin masyarakat komunitas adat terpencil seperti suku asli yang ada dikecamatan bantan yang mana dibeberapa desa dikecamatan bantan terdapt suku asli dan kami juga selalu meningkat kan kualitas hidup masyarakat komunitas adat terpencil dan mensejatrakannya dalam bidang apapun serta melestarkani kegiatan atau hasil kerja yang diperoleh oleh masyarakat Komunitas Adat Terpencil.

Selanjutnya berdasarkan hasil wawancara penelitian dengan Batin suku Akit yang ada di Desa Jangkang mengatakan bahwa selama ini pemerintah tidak ada membedakan kami dengan masyarakat yang lain, disemua sektor mulai dari pendidikan, kesehatan dan lainnya kami memiliki hak yang sama dengan masyarakat lain dan bahkan pemerintah melindunggi hak-hak kami supaya tidak dilanggar. Dalam hal pemberian bantuan hukum bagi masyarakat Komunitas Adat Terpencil yang mengalami permasalahan dengan hukum, dari hasil temuan penelitian dilapangan belum ada upayan pemberian bantuan hukum kepada masyarakat Komunitas Adat Terpencil yang bermasalah dengan hukum, selama ini masyarakat Komunitas Adat Terpencil selalu menyelesaikan permasalahan mereka melalui jalur adat sesuai dengan aturan dari leluhur mereka.

Disamping itu pemerintah daerah juga belum aktif dalam memantau masyarakat Komunitas Adat Terpencil yang tersangkut dengan persoalan hukum sehingga pemerintah daerah banyak yang tidak mengetahui sehingga terabaikan hak mereka untuk memperoleh bantuan hukum.Dari hasil wawancara penelitian dengan Kepala Bidang Pemberdayaan Sosial Dinas Sosial Kabupaten Bengkalis mengatakan bahwa kami dari Dinas kesulitan untuk mendeteksi masyarakat Komunitas Adat Terpencil yang bermasalah dengan hukum, mereka tidak ada yang melapor dan lebih banyak menyelesaikan permasalahannya sendiri. Selanjutnya hasil wawancara penelitian dengan salah seorang masyarakat Komunitas Adat Terpencil mengatakan bahwa memang selama ini mereka mengetahui kalau ada permasalahan dengan hukum pemerintah daerah akan memberikan bantuan hukum karena pemerintah daerah Kabupaten Bengkalis pernah mensosialisasikan hal tersebut, akan tetapi mereka bingung harus melapor kemana ketika membutuhkan bantuan hukum tersebut.

Berdasarkan uraian tersebut diatas dapat disimpulkan bahwa pemeberdayaan Komunitas Adat Terpencil yang dilakukan oleh Pemerintah Daerah Kabupaten Bengkalis belum berjalan secara maksimal, hal ini bisa dilihat dari upaya pemberdayaan sumber daya manusia Komunitas Adat Terpencil belum ada upaya konkrit yang dilakukan oleh pemerintah daerah, sejauh ini hanya sebatas pemberian bantuan baik dibidang kesehatan, pendidikan maupun yang lainnya, sedangkan upaya peningkatan kualitas sumber daya manusianya belum ada. Demikan juga hal dalam pemberdayaan lingkungan sosial Komunitas Adat Terpencil pemerintah daerah Kabupaten Bengkalis baru sebatas memberikan bantuan rumah layak huni dan penampungan air bersih sementara tentang pemahaman akan pentingnya pola hidup sehat belum ada upaya dari pemerintah daerah, sedangkan dalam hal perlindungan sosial dan advokasi, khusus dibidang perlindungan sosial pemerintah sudah melindungi hak-hak masyarakat Komunitas Adat Terpencil dari segala bentuk diskriminasi tetapi dalam hal pemberian bantuan hukum baru sebatas 
sosialisasi dan slogan sedangkan tindakan nyatanya belum ada sehingga masyarakat Komunitas Adat Terpencil kesulitan untuk mengadu.

\section{KESIMPULAN}

Pemberdayaan Komunitas Adat Terpencil yang dilakukan oleh Pemerintah Daerah Kabupaten Bengkalis pada dasarnya belum berjalan sebagaimana mestinya dimana upaya-upaya yang sudah dilakukan baru sebatas pemberian bantuan sarana dan prasarana baik dibidang pemberdayaan sumber daya manusia, lingkungan sosial maupun perlindungan sosial dan advokasi, dan bahkan bantuan yang diberikan tersebut masih banyak yang elum dimanfaatkan oleh masyarakat Komunitas Adat Terpencil. Berdasarkan hasil observasi dan wawancara dengan berbagai informan yang sudah ditetapkan maka ditemukan beberapa hambatan dalam proses pemberdayaan masyarakat Komunitas Adat Terpencil tersebut yaitu :

1. Masyarakat Komunitas Adat Terpencil belum bisa menerima hal-hal baru karena mereka takut budaya leluhur mereka menjadi memudar.

2. Masyarakat Komunitas Adat Terpencil masih tertutup dari pihak lain, mereka hanya berinteraksi sesama masyarakat Komunitas Adat Terpencil.

3. Masyarakat Komunitas Adat Terpencil belum bisa meninggal kebiasaan leluhur mereka dalam menjalani kehidupan sehari-hari.

4. Terbatasnya anggaran dalam melakukan pemberdayaan, karena pemberdayaan itu butuh proses berkesinambungan.

Adapun saran yang dapat dijadikan sebagai bahan masukan dalam pemberdayaan Komunitas Adat Terpencil oleh Pemerintah Daerah Kabupaten Bengkalis adalah Kepada masyarakat Komunitas Adat Terpencil disaran supaya lebih membuka diri berinteraksi dengan masyarakat lain dan menerima hal-hal baru yang sifatnya positif. Kemudian Kepada Pemerintah Daerah Kabupaten Bengkalis disarankan supaya anggaran untuk pemberdayaan ditambah sehingga pemberdayaan dapat berjalan maksimal

\section{DAFTAR PUSTAKA}

Arikunto, S. (2006). Dasar-Dasar Evaluasi Pendidikan (Revised Edition). Bumi Aksara, Jakarta.

Aziz, H. M. A., \& Halim, A. (Eds.). (2005). Dakwah pemberdayaan masyarakat: paradigma aksi metodologi. Pustaka Pesantren.

Azizy, A. Q. A. (2007). Change management dalam reformasi birokrasi. Gramedia Pustaka Utama.

Budi, W. (2008). Kebijakan Publik: Teori dan Proses. Edisi Revisi. Yogjakarta: Media Pressindo.

Dunn, W. N. (2000). Pengantar Analisa Kebijakan Publik. Edisi Kedua, Gajah Mada.

Hanif, N. (2005). Teori dan Praktik Pemerintahan dan Otonomi Daerah. Jakarta: Grasindo. Hariyoso, S. (2002). Pembaruan birokrasi dan kebijaksanaan publik. Peradaban.

Huraerah, A. (2008). Pengorganisasian dan pengembangan masyarakat: model dan strategi pembangunan berbasis kerakyatan. Humaniora.

Islamy, M. I. (2002). Prinsip-prinsip perumusan kebijakan negara..

Keputusan Presiden Nomor 111 Tahun 1999 Tentang Pembinaan Kesejahteraan Sosial Komunitas Adat Terpencil

Muhadam, L. (2007). Memahami Ilmu Pemerintahan. Raja Grafindo, Jakarta.

Ndraha, T. (1997). Metodologi ilmu pemerintahan.

Ndraha, T. (2008). Kybernologi Sebuah Metamorphosis. Jilid I, Sirao Credentia Center, Banten. 
Nugroho, R. (2003). Kebijakan Publik, formulasi, Implementasi dan evaluasi. Jakarta: Elex Media Komputindo.

Patilima, H. (2005). Metode penelitian kualitatif.

Pranarka, A. M. W., \& Moeljarto, V. (1996). Pemberdayaan (Empowerment) dalam: Pemberdayaan: Konsep, Kebijakan dan Implementasi. Disunting oleh Onny $S$. Projono dan AMW Pranarka. CSIS: Jakarta.

Rasyid, M. R. (2000). Makna Pemerintahan: Tinjauan dari segi etika dan kepemimpinan. Mutiara Sumber Widya.

Sedarmayanti, G. G. (2003). Dalam Rangka Otonomi Daerah. Mandar Maju, Bandung.

Subarsono, A. G. (2012). Analisis kebijakan publik: konsep, teori dan aplikasi.

Sugiyono, P. (2001). Metode Penelitian Administrasi (edisi ke-3). Jakarta: Alfabeta.

Suharto, E. (2010). Membangun Masyaraka, Memberdayakan Rakyat: Kajian Strategis Pembangunan Ksesejahteraan Sosial dan Pekerjaan Sosial.Bandung. Rafika Aditama.

Suharto, E. (2015). Analisis kebijakan publik: panduan praktis mengkaji masalah dan kebijakan sosial.

Suhendra, K., \& Kadmasasmita, A. D. (2006). Peranan Birokrasi dalam Pemberdayaan Masyarakat. Alfabeta.

Sulaeman, A. (1998). Diktat Kebijakan Pemerintah.

Sumaryadi, I. N. (2005). Perencanaan pembangunan daerah otonom \& pemberdayaan masyarakat. Citra Utama.

Supriyatno, B. (2009). Manajemen Pemerintahan, CV. Media Brilian, Tangerang.

Suyanto, B. (2015). Metode Penelitian Sosial: Berbagai Alternatif Pendekatan. Prenada Media.

Suyatno, H. (2003). Pengembangan masyarakat: dari pembangunan sampai pemberdayaan. Aditya Media.

Syafiie, I. K. (2011). Sistem Pemerintahan Indonesia.

Taliziduhu, N. Kybernologi (Ilmu Pemerintahan Baru), 2003, PT. Rineka Cipta, Jakarta.

Tangkilisan, H. N. S. (2003). Kebijakan publik yang membumi. Yogyakarta: Lukman Offset.

Tangkilisan, H. N. S. (2003). Teori dan Konsep Kebijakan Publik" dalam Kebijakan Publik yang Membumi, konsep, strategi dan kasus. Lukman Offset Dan YPAPI, Yogyakarta.

Teguh, A. (2004). Kemitraan dan model-model Pemberdayaan. Yogyakarta: Gava Media, 2.

Wibawa, S. (1994). Kebijakan publik. Jakarta: Intermedia.

Widjaja, H. A. W. (2003). Otonomi Desa: merupakan otonomi yang asli, bulat dan utuh. PT. RajaGrafindon Persada.

Winarni, T. (1998). Memahami Pemberdayaan Masyarakat Desa Partisipatif dalam Orientasi Pembangunan Masyarakat Desa Menyongsong Abad 21: Menuju Pemberdayaan Pelayanan Masyarakat. Yogyakarta: Aditya Media. 